\title{
Expert In-depth Interview on Development and Efficiency of "RIGA International Airport" Reflecting Factors
}

\author{
Sergejs Paramonovs ${ }^{1}$, Ksenija Ijevleva ${ }^{2}$ \\ ${ }_{1,2}^{1}$ University of Latvia
}

\begin{abstract}
The aim of the paper is to identify development ways and effectiveness of RIGA International Airport. Theoretical evidence was examined and expert in-depth interview was carried out to explore the main circumstances affecting RIGA International Airport functioning. Findings of the study show that there are positive tendencies in the field of airport efficiency and development, but improvement is needed primarily for coordinating visions and resources managed by both state and airport administration bodies.
\end{abstract}

Keywords - Airport development, expert in-depth interview, factor analysis, RIGA International Airport.

\section{IntRoduction Within a CONTEXT of Global Competitiveness}

Globalisation influences aviation in a similar to other industries way. The processes are getting more and more complicated and interrelated with time. Contemporary countries are not isolated one from another, neither are its industries. For the modern day airdrome to be successful, competitive and developing, its administration has to keep coming with solid and creative ideas reflected in the way a plan of development realised. An airport is a spinning point of the industry, where all the factors influencing its development come to interplay for the benefits of passengers, enterprise and society as a whole. It is important to understand the factors and their influence on airport development. Thus, the purpose of paper is to identify development ways and effectiveness of RIGA International Airport.

In Latvia, the Law on Aviation defines an airport or aerodrome as a "specified land territory or water aquatorium, as well as the buildings, objects and equipment which are fully or partly intended to organize the arrival and departure of aircraft (that is the take-off, landing, taxiing and standing of aircraft, the embarkation and disembarkation of passengers, services for transit passengers, the loading and unloading of baggage, as well as servicing, fuelling of aircraft." Experts from Oxford University have estimated that the aviation industry in Latvia gives 2\% to Gross Domestic Product (GDP) and provides employment to 20000 residents involved in both aviation and non-aviation services and works.

Andersson Granberg and Oquillas Munoz (2013) called airports "essentially intermodal stations." While functionally defining those as places where "passengers are arriving by airplane and continue their journey by ground transportation or transferring to another flight," they stressed importance of businesses growing on the ground of those. The more passengers meant the bigger airports were needed and the more business was generated for involved corporations (Assaf, 2009). As time passed, airports grew into important industries for the countries where they are located (Allroggen \& Malina, 2014). The researchers concluded: "It is essential that the airports are reliable and efficient. However, due to the complexity of the enterprise operations, this is not an easy task." In their work they further elaborated and offered a concept of evaluating performance of an airport.

Often, state of global, regional or local aviation industry is one of the prominent indicators of present day societies' development and their potential for raising competitiveness in the future. The best technologies available at present can be found at airports across the world. However, present day aerodromes are very complex enterprises, and an urgent need for comprehensive evaluation of their performance becomes imperative, as it is directly linked to ecological issues and safety of passengers.

Robinson formulated globalisation as: "new systems of production, finance, consumption and worldwide economic integration; global culture and political processes; rise of new transnational institutions; multidirectional movement of people around the world; new patterns of transnational migration, identities and communities; as well as new forms of hierarchies and forms of inequality" (Robinson, 2008). All that can be applied to the operations of an airport. Ultimately, globalisation is a factor of development of an airport itself. This is a phenomenon, which Robertson called "the compression of the world and intensification of consciousness of the world" (Robertson, 1992). He is right, as a modern day airport is involved into massive amount of transactions at the given period of time. There are more flights and passengers processed then before. Even a small airport is a very complex enterprise with many technologies and resources involved.

Administrations and employees of a contemporary airport have to manage more events and elements in their mind, so their efficient performance becomes impossible without strictly following codes and instructions, but at the same time they should be flexible and ready to deal with non-standard situations at any moment (Ahn \& Min, 2014). This becomes crucial to eliminate a probability of occurrence of a mistake or any accident. For that reason, every airport employee knows his area of competence, but at the same time, it is crucial to coordinate his or her activities with colleagues and administration. A personality of an employee is left important, even in a highly technological airport. This is where investments into human resource departments and training centres pay themselves back (Teperi\& Leppänen, 2011). Though, related changes are not limited to instrumental and human factors. 


\section{Contemporary Aspects of Aviation Industry}

There is a major paradigm change related to ownership of airports (Mantin, 2012). In the past, it was common to consider airports to be a strategic element of infrastructure by governments around the world. By that reason only, parliaments kept airdromes in state ownership. But, changing reality and more stable world made it possible for governments to consider a complete or partial delegation of ownership or management rights to private institutions; like a quasi-private firm "Fraport" is managing Germany's Frankfurt Airport; or an example of Vienna Airport whose stocks are publically traded.

A majority of commercial airports in the world are still owned and managed by local Transportation or Airport Authorities (Oum, Yan \& Yu, 2008). In some cases, airports being stateowned delegate operations to private corporations and consortiums, in some cases - to international businesses.

In the United Kingdom, for example, the state-owned British Airports Authority originally operated eight of the nation's major commercial airports, but downsized to operating just five in the year 2006, when the Spanish Ferrovial consortium took over the rest after privatisation. And that has happened despite the fact that British airports are always among the leaders in Europe in terms of turning passengers per annum and other categories.

Another major change in the industry noted is that full service airlines have to share business with discounters, but actually not (Pels, 2008; Diaconu, 2012). There were times when a lot of people could not afford either taking flights at all or took them relatively rarely due to high costs of traveling by air. Discounter airlines, like EasyJet, Southwestern or RyanAir created a new segment of business for those who could not afford taking flights before. Today, there are simply more people traveling then before. The industry is taking a new turn.

Small airdromes all over Europe are getting another chance to rush into the twenty-first century. Sometimes, former military or dying airports receive a chance for new life. Small airports like Skavsta in Sweden are located in remote locations from the capital, but become important connecting hubs for extended flights. The airport in Sweden does not offer the most convenient direct flights, but numerous connections may take a passenger in any direction at a very reasonable price. Typically, a passenger would stay overnight in a cosy and cheap hotel to take another flight next morning. At the same time, transportation companies providing services to and from Stockholm give airlines' passengers an opportunity to see the capital of Sweden keeping their budget tight. It is possible that Latvia's airports in Liepaja, Jelgava or Tukums may get such a chance in the near future as well.

A role of international organisations regulating the industry or linking airports in different countries is hardly possible to overestimate. Industry alliances, like International Civil Aviation Organisation (ICAO), strictly regulate airport operations. Accepted by members, industry standards are distributed and enforced to make experience of passengers as safe and comfortable as possible. Airports Council International (ACI) is an international association of the world's airports with a goal of fostering co-operation among its member airports and with other industry partners, including governments, airlines and aircraft manufacturers. The co-operation results in an air trans- port system that is safe, secure, efficient and sustainable. One of the important missions of the organisation in the information age is to provide member airports with timely information and analysis of domestic and international developments. This is a direct link to the future.

In this paragraph, the authors make an attempt to understand the modern age industry novelty to vision the airport of the future? Manuel Castells in his understanding of globalisation claimed: "The humanity is moving toward "network society" with its new way of communication among its members" (Castells, 1998). According to his new technological paradigm: "Human society moved from verbal and audiovisual perception to integrative technological." It is known, we are on the verge of technological breakthrough in aviation and airport management. Soon, airports will be very different establishments with minimum involvement of humans. In the USA, the Federal Aviation Administration (FAA) is planning to replace existing groundbased radars and control towers with a new satellite technology. As a result, a timetable of flights will be used only if it is needed. After installing new age Global Positioning Systems (GPS), it sounds unrealistic, but to airplanes freedom will be given to land not by schedule, but by request. According to the plan, aircrafts on destinations with high intensity passengers' traffic, like from New York to London, will stand and wait for free-coming passengers to fill available seat capacity. Once filled in, the aircraft will take off, like a taxi. All this is important to know in order to vision and properly plan development of the local airport in Riga. Unfortunately, an existing Plan of Development of RIGA airport until 2036 does not suggest anything like this; it is rather very conservative and takes our airport into the past, not future.

A contemporary airport is involved in both cooperation and competition with other airports in the region. There is always a question: Why would a passenger travel to a particular aerodrome, especially if this is only a transit destination? Or what would make a passenger to pick, let us say Vilnius or Tallinn airport instead of RIGA? Obviously, today more passengers pick RIGA due to such reasons as convenience, comfort, and offered number of destinations. But what if, there were a highspeed train connecting three capitals, or even taking passengers further. The situation might lead to new opportunities for neighbouring airports and also introduce a new competitor to them, a railway company. Adding conference centre, top-rated hotel, or employing staff speaking Arabic, Chinese and other languages may attract more passengers who never considered this location before. Successfulness of any airport is limited to an ability of predicting future trends in the industry. The following story gives such an example.

British architect Sir Norman Foster called "Tempelhof a mother of all airports" (Smee, 2008). For a century of its life cycle, the airdrome pioneered with numerous solutions, which later became a "golden standard" for new airports all over the world. Every stage of its development was always a historical milestone. Wright brothers were the first to fly a steered motorised aircraft; records breaking flights originated there; and all sorts of flying apparatus were tested there that typically attracted masses of public. In 1923, Tempelhof was the first to build runaways, hangars and airport main building, as well as to start regular 
commercial flights. That was the place where Lufthansa started its way in 1923. One year later, it was the only airdrome in the world having an underground train station, Paradestrasse, due to dramatically increased passengers' traffic. According to the Tempelhof Airport official website, in the days, the airport was serving 200 thousand passengers, which was an absolute record no other enterprise was even trying to beat.

Further development and new era came with ambitions to serve up to six million passengers per year. What happened next became a contemporary standard for any project of an airport today. There was a new vision introduced, where different levels were used for arrivals and departures, passenger and cargo flights were separated, as well as congress halls, office facilities, restaurants, and shops found its new venues for expansion. After World War II and under the patronage of America's occupational forces, the airport set a new record with flights landing and taking off every 90 seconds. The truth is that ambitious plans of the masterminds of the project never fully came true, and the airport slowly lost its attractiveness and finally was closed in the year 2008. But, this is not the end of the story at all.

As of today, Tempelhof is both a conference facility and a park. In 2012, the venue publicly repositioned itself as an international event location for trade fairs and conventions. The rest of the buildings were renovated to improve energy efficiency and converted into a creative and start-up centre. In 2013, "e-THF - Tempelhof Electro-mobility Competence Centre" was opened. Information bureau, a showroom and a driving track were opened for personal experience. Summarising, the historical flagman of all airports gives an example of how the airdrome may develop into the best venue of its kind in the world, then lose its momentum and, finally, totally shifts the way of its development.

This unprecedented example of long-term commitment and proactive management, as well as employment of the best professionals and ideas gives us inspiration and directions at the local level. The authors believe that a management approach used at glory days of Tempelhof, the initiative and progressive innovative ideas of their teams are occasionally employed at airports in the Baltic Sea region, like Copenhagen, and must be employed for taking RIGA International Airport (further RIGA airport) onto new levels, which are not even seen for the moment.

It is common to differentiate meanings for the terms of effectiveness and efficiency. In the authors' opinion, the idea under the term of effectiveness is quality. The better quality results are reached, the more effective an individual or a process is. Considering the effectiveness of RIGA airport, one may evaluate its operations as effective, whenever his/her subjective satisfaction rate is high on the scale from one to ten. For example, a security check point officer is effective, in case $\mathrm{s} /$ he thoroughly follows the procedures and additionally uses his/her natural gut feeling to prevent occurrence of incidents with passengers carrying forbidden items onto the aircrafts. However, the effective officer may not be efficient, when time and number of passengers served become crucial. For instance, during morning and evening rush hours the effective work only may lead to passenger traffic congestion, and, as a result, to losses to the air-carriers and insurers due to paid compensations for missed or delayed flights.
Quality of operations of modern airports is both effectiveness and efficiency driven. The security check point officer must be efficient and effective at the same time. Time and number of passengers checked are very important as well. To produce efficient results along with being effective, the officer has to apply strategies that help serve more passengers for the least amount of time possible. For example, the officer may ask queuing passengers to take their top cloth off or prepare their stuff for checking in advance.

The terms of effectiveness and efficiency may be and often are mutually exclusive. Efficiency is about reaching better productivity but effectiveness is related to quality. The performance of an airport or specifically its management may be better understood in terms of how well the management is able to balance quality and productivity.

However, one may realise that passengers' satisfaction is subjective and may reflect on both at the same time. For the passengers both qualities, effectiveness and efficiency, are very important because they enable passengers to receive high-quality service for the minimum time possible.

\section{Methodology}

The authors conducted expert in-depth interviews at RIGA airport to identify factors significantly influencing development and effectiveness of RIGA airport, as well as to improve the situation finding its reflection in present global and regional airfield rankings and somewhat stagnant present indicators of its performance.

Expert interview is one of the most important qualitative data collection and research methods. It is widely used in field studies and ethnographic research. Even if it is not the primary method of data collection, the interview technique is often used as a pilot study to gather preliminary data prior to conducting the quantitative survey (Kvale \& Brinkmann, 2009).

Quantitative research proponents consider qualitative empirical data, which are obtained by methods such as expert interview, "unreliable, impressionistic and biased" (Jepsen \& Rodwell, 2008). The researchers believe that the interview is nothing more than a casual talk. However, compared to the daily conversations, which usually occur between participants on an equal footing, the interview can be more described in terms of power asymmetry, where an interviewee reflects onto the more or less superficial, but sometimes naive researcher's vision of a situation (Sandy \& Dumay, 2011).

Although, it seems that anyone can easily ask questions, but poorly prepared and thought-through interviews are likely to cause modest results, such as those which may be called a "wasted opportunity" (Minichielle, Aroni \& Hays, 2008). Hence, while conducting the qualitative research, in this case an expert survey, it is not only required to use different skills, such as "intense listening" and taking notes, but also careful planning and adequate preparation (Granot, Brashear \& Motta, 2012).

For useful interview data collection, researcher's experience and knowledge of the subject are essential. If this is the case, a researcher is able to ask informed, accurate and deep questions, as well as to conduct an interview on the basis of inter- 
viewee's answers. Interviewing requires a subject to relate with respect and inquisitiveness to what an interviewee says, as well as a strenuous effort to listen and understand what is said is required (Hammersley, 2007). Plus, while preparing and designing an interview, one has to make important decisions regarding a body of participants, procedures to employ and following data processing techniques (Dumay, 2009).

The authors have used semi-structured in-depth expert interview as one of the primary methods of data collection. This qualitative part of the study is to obtain the views and opinions of experts and in-depth information on a situation and factors affecting the development of RIGA airport. Specific questions were elaborated and discussed with experts during the interviews.

Interviews were designed and adapted to the content of the questions in order to obtain expert opinions and information while assessing issues that were not possible to measure by means of a quantitative survey, like the overall, bureaucracy or political situation. For instance, it became known from the interviews that political and ownership related factors were the most influencing ones and directly influenced performance of the airport. To prove the statement, it is worth mentioning the fact that for the previous five years, RIGA airport was not able to significantly increase its efficiency related indicators, such as passengers transported and profitability.

Expert Questionnaire procedure was the following: the authors had created a list of individuals, who supposedly could qualify as experts, as it was reflected in the expert selection criteria. Contacting the experts by email and in person followed.

Expert selection criteria:

- Being fluent in English;

- Having work experience in a leading operation role at RIGA airport, at present or within the previous five years;

- Having the work experience for over a year;

- Job description of an expert should include evaluation of efficiency of RIGA airport;

- An expert should be knowledgeable of top airport KPI or efficiency evaluation models around the world;

- An expert should be knowledgeable of regional versus global competition;

- An expert should have published articles on the issue of airport efficiency.

Guidelines for the interview were distributed into the following categories:

- Factors and obstacles;

- Efficiency measurement concepts;

- Profile and satisfaction of passengers;

- Vision for airport development and private opinion.

Expert in-depth interviews were carried out in the first half of 2014. This paper further follows with the description of the interviews and authors' generalised overview. Experts' quotations from the interviews are cited further in italics.

Whilst conducting the study, the authors interviewed three experts:

1. Former CEO and chair of the board of RIGA airport;

2. Deputy of CEO and a member of the board of RIGA airport;

3. Director of Latvian Civil Aviation Agency.
Therefore, there were three interviews conducted to reveal the factors that might influence the development of RIGA airport. Three former and existing board members of RIGA airport kindly agreed to be interviewed about the matter.

\section{EMPIRICAL ANALYSIS}

The interviewees appeared to be knowledgeable of factors influencing the development, but at their work did not use any established or widely used concept of airport efficiency tracking. There was no expert relying or trying to rely on any established performance monitoring model. The experts were very busy whilst being overwhelmed with daily routines of the airport. Yet, separate attempts were made to strongly increase the efficiency of operation by changing a structure of ownership, employing available on the market software and methods of ergonomics. To our regret, nothing was implemented up to now, as major activities at the establishment had to be taken through the transportation authority. Numerous attempts at the Ministry of Transport ended up with complete failure.

The interview questionnaire was created based on the idea of finding the most influential factors reflecting on the airport development, i.e. the factors that might predict steady development on the long run. Earlier in the paper the authors cited numerous sources stressing that there should be a comprehensive model of performance or effectiveness monitoring, rather than an analysis of individual factors. That is why, the concept of Granberg and Munoz became the only one closely related to the situation at RIGA airport. The concept is seen by its authors to become a model for efficiency monitoring and mapping the way to reaching stressed goals in the plan of development. The crucial aspect is that the international aviation industry is at the stage of transition from state-owned to private enterprises, which creates ground for major changes in approaching the effectiveness. The experts recognised that state-owned management of the airport was much less efficient than private or partly private businesses. The existing examples of the airports in Vienna and Amsterdam show promising results of this transition.

To start, the experts were asked whether they know and share a mission statement, vision and strategic goals for the airport efficient operations. It is worth saying, before talking to experts, all three guiding entities were difficult to find anywhere in the available documents or on the website of the airport. After taking a quick look into his papers, the second expert clearly formulated all three. For the sake of the importance for the paper, the authors cite those below separately.

Mission: to provide passengers with high quality, safe and reasonably priced air-carrier and cargo services, while maintaining and developing infrastructure and operations at industry international standards.

Vision: State Joint Stock Company (SJSC) RIGA International Airport is positioned as a profitable and dynamically developing establishment competing European Baltic and Nordic Air Hub, which further spreads a network of flights toward both East and West, as well as stimulates transit passengers' volumes to grow and capacity of turned over cargo to increase. 
Strategic goals: (1) to increase competitiveness of the airport along with passenger and cargo volumes; (2) to insure the infrastructure maintenance and development; (3) to ensure that development is sustainable; (4) to ensure high safety standards; (5) to ensure high quality of airport services; (6) to stimulate commerce and business development; and (7) to ensure stable and secure financial state of the airport.

The second question was about factors strongly influencing RIGA airport development and ranking among competitors. All experts agreed that geographical location is a point of strength for the airdrome, as there are three capitals within its 300-kilometer zone around the field. One of the experts added that the airport in Tallinn is surrounded by non-Schengen Russia, Baltic Sea and a very strong competitor in Helsinki (Vantaa airport), but the airport in Vilnius faces similar problems being in proximity with non-Schengen Belorussia and Russia, as well as Poland and Latvia. Altogether, in the given political and economic situation, it makes location of RIGA airport the best in the Baltics. The third expert pointed out that RIGA airport was benefitting from being located right outside the city, not inside, unlike Tallinn and Vilnius, which might experience serious problems while planning further development, in case volumes of passengers served would surpass its capacity.

While answering the question, the experts highlighted numerous factors strongly influencing performance and efficiency of the airfield. Many of the factors were clustering around ownership and economics of the airport. One of the experts clearly stated: "The only way to move forward in reaching the goals is to change ownership structure, while bringing more shares of privately owned capital." The second expert continued: "One more option to do so is to delegate or sell the operational rights to private businesses. Otherwise, decision making is slower and not always efficient, as the airport administration has to, not just coordinate, but approve their daily decisions at the Ministry of Transportation." The third expert added: "The majority of the airport employees are civil servants that makes labour management very inefficient. Once the administration employed them, they receive salary independently of volume, quality and number of tasks completed. It was calculated, if the company used outsourcing cleaning services, it would save $30 \%$ of labour expenses." There are examples provided on how previously mentioned factors slow the process of reaching goals established in the Plan of Development until 2036 by RIGA International Airport.

Answers to the third question covered obstacles to reaching the goals. Many of those had already been explained while discussing problems themselves. To add, one of the experts mentioned ever-changing air-carrier market. In his opinion: "Airlines operate very complex businesses, but margin they operate with is minimal, as low as 1 to $2 \%$. This makes operations very vulnerable against numerous risks, like downfalls in economy or raising fuel costs. At the same time, anti-monopoly committees restrict any support of airlines on the government's part to guarantee free competition to all participants on the market. One of the recent failure market examples is Hungarian Airline, MALEV, which bankrupted in February 2012. It has a direct impact on operations of RIGA airport, as its CEO is in charge of AirBaltic right now."
Air-carriers' financial discipline is a serious issue, accordingly to the experts. They explained that many air-carriers were either not paying at all, like Ryan Air, or paying extremely inconsistently, like AirBaltic. "An example of AirBaltic from the recent history is outrageous," an expert said. "Berthold Flick, former CEO of AirBaltic, by his voluntary decisions would avoid paying airport fees for months. At the same time, he was receiving his salary of LVL 13300 per month plus bonuses on time. At some point, the air-carrier owed to the airport seven million euros. When he was several times reminded about the issue, he always became angry and called a prime minister to receive another extension to pay. Now it is publically known, he was not planning to pay, and it is reflected in a criminal case pressed against him", the expert added. No wonder, the airport suffered lack of finances for a long period of time. The expert complained: "At present, many works toward fulfilment of the Plan of Development are stopped due to lack of finances. The problem becomes even more complicated, if one takes into consideration that the second largest air-carrier at RIGA airport, Ryan Air, is not paying even a cent, but receives 500 euro per each landing from the city of Riga." "The company is not paying for any accompanying services either, but receives those for free. Just to remind, the airport is not receiving anything from landing NATO aircrafts according to an existing agreement. The agreement any member country signs states that alliance' transports and forces use the stateowned facilities of the members for free," the expert continued.

Airport tariffs are regulated by the local transportation authority and are kept extremely low. One of the experts explained: "Regretfully, our airport fees are as low as two euro per local and one per transit passenger. At the same time, it is a common practice for the majority of European airports to charge ten euro, but airports in Asia would charge up to 30 euro per passenger." AirBaltic dominates the flight schedule with $63 \%$ coverage due to limited or unfair competition. One may complain that increased airport fees would reflect on raised prices for flights, but the expert exclaimed that "prices of AirBaltic are higher than those of many competitors!" This is purely a question of a voluntary decision to make airport fees at an adequate level. The expert would suggest an airport fee of at least seven euro that still would be lower than in all the competing airports. The fee per passenger would let the airport run all the operations and develop its infrastructure without help from outside, the expert concluded.

Answering the question about whether experts plan their activities in their professional role according to the existing Development Plan of RIGA International Airport until the year 2036, all experts agreed that the document existed as a general guideline, but in their daily activities they would rather be guided by ongoing issues only. Lack of financing and unnecessary bureaucracy at the level of Ministry of Transportation would restrain any initiative and limit activities to only following international aviation authority guidelines of safety and standards for airports, they said. An expert confirmed these words and admitted that all his efficiency improving proposals were either turned down by the authorities, or cancelled by interested parties themselves due to re-evaluation of business related risks. A primary risk the businessmen would typically articulate was "state administration, which would govern not on efficiency, but political coalition 
principle." The expert gave an example of daily 800 kilograms of trashed wastepaper at airport. "Instead of selling it to companies for recycling, the airport pays to waste management companies to collect it. A businessman offered to the administration of the airport to press wastepaper and further take it to a recycling site, but withdrew his offer being afraid of later losing his business due to often changing administration. As a result of this mismanagement, the airport keeps paying a total of EUR 10,000 a month for waste management," the expert told. The same was true, according to the expert, with de-icing solvent waste. This problem will be discussed later in this section.

Although all the experts admitted that there were no systematic attempts of finding and applying a standardised and validated operation efficiency model to RIGA airport within the previous five years, one of them told about his attempt to introduce software managing efficiency of daily operations at the airport, including tracing airplanes in the air. He recalled: "The software would cost only a million euro, but guarantee $30 \%$ reduced staff. This would result in payback in less than 12 months. Unfortunately, any expense over EUR 132,000 must be approved by the Ministry of Transport. However, like always, the offer was turned down. As of today, like decades ago, there are three female employees keep tracking daily activities, including in the air, by means of paper, pencil and a straightedge." Another expert, while replying to the sixth question about actually using the efficiency models or concepts, said: "the airport administration and supervisory Civil Aviation Agency monitor and rely exclusively on international standards established by ICAO (International Civil Aviation Organisation)." In other words, nobody really keeps in mind the Plan of Development.

The questions seven through ten were targeting opinions of experts on the concept of Granberg and Munoz of Linkoping University. Actually, only one expert knew about the concept and claimed he knew it was standardised. None of experts actually used the performance factorial model in their daily work. And opinions of the experts divided at this moment on scale it was applicable to operations at RIGA airport at the given time and situation. One of the experts clearly insisted it was a useful concept reflecting on factors showing efficiency of the airport at any given moment. The second expert had an opinion that his real responsibility was only to track implementation of local and international laws and regulations. The third expert was more radical in his opinion. He said: "This is an interesting concept, but its usefulness for RIGA airport is very limited. All the operations here are strictly standardised and monitored by supervising authorities. For further development much investment will be needed."

There were different opinions of experts concerning the importance of delay monitoring, which was asked in question ten. Just to remind, Granberg and Munoz suggested that in no time the efficiency of an airport could be reflected in monitoring delays only. They speculated, the delays were ultimate indicators of efficiency. In their opinion, if everything was working smoothly, then there would be no delays in airport functioning. The previous expert clearly said there was no reason to pay any special attention to delays, as this indicator was strictly regulated by the aviation and local supervisory authorities. He reminded: "It is regulated to serve a passenger within one hour from the moment an airplane is landing to the moment the passenger is leaving a baggage receiving area and customs facilities, or taking a bus, taxi or a car from a parking lot. RIGA airport is small enough, so delays at landing are rare. Minor delays are possible at departures, but the problem is minor." Another expert, on the contrary, supported the authors of the concept saying: "The fact that it is not applicable to the operations at RIGA airport is only to respect daily efforts of administration, employees and supervisory bodies, who work hard to eliminate delays. If let it go, delays will take place immediately. RIGA is a very punctual airport and it shows that we are effective. The model of Granberg and Munoz applicable to delays is fair."

As for ranking part of the concept, which is stressed in question eight, Airport Economy was the only block in the concept considered to be the most important by all experts, who believed it showed much room for performance improvement. Somewhat lower rank was given, but all the experts still highlighted importance of Airport Environmental Issues. One of them gave several examples of how to improve efficiency by stressing environmental issues. He told, for instance: "The airport doesn't have a platform for collecting a de-icing solvent after it is dispensed onto the aircraft. 800 kilograms of the solvent per aircraft are simply released onto the ground and soaked into soil immediately afterwards. Despite the lost profit from not using a simple process of recycling of the solvent into windshield washing fluid for cars, like it is done at Helsinki Airport, it creates a serious hazard to the surrounding environment."

Airport economy was given the presidency of all other parts of the concept by all experts. That was the ground where many examples were drawn from their experience. There were two ways of improving economy of the airport, experts explained, optimising existing processes and creating new venues for increasing revenue. Introducing the optimisation software, as well as outsourcing cleaning services would create economy of $30 \%$ from each initiative. "The airport employs more than 1300 employees. $30 \%$ is about 400. Average expense per employee is 1000 euro per month. Total, four million euro can be saved on optimisation software only, which cost a million euro," expert clarified. "One hundred thousand euro can be saved, if cleaning services are outsourced," he added.

Another expert told about strange airport practices of buying toilet paper. He recalled: "It is a very complicated and a multistep process. There are six to seven airport employees involved into it. Whenever decision of buying the paper is made, then, every time, they prepare a specification and conduct a tender. At the same time, other employees prepare a document where they substantiate that the paper will not be stolen or used improperly." Obviously, the process as simple as that should be done with fewer human resources involved. Common practice at major European event venues is to plan 2\% for unexpected loss. It is suggested to start an investigation, only in case of surpassing the limit. The needed software tracking the processes at airport would immediately show such extra usages," he concluded.

One of the problems in the economic sphere was called by one of the experts outrageous. By voluntary decision not coming from the Board, he explained, the most profitable business 
of the airport, ladder or trap services were given out to Turkish company Havas. "If not lost, the business would give 3.5 million net profits after four years only. For the period, all the expenses related to buying needed equipment would be paid off," he claimed. The same expert informed that RIGA airport did not have a cargo warehouse for transported fruits and flowers. He said: "Transporting and storing electronics, fruits and flowers are a strong source of income for both airlines and airports. In the period, when cargo traffic through the airport shows strong increases, which is not true about passenger traffic, we have to plan the development of warehousing and better related infrastructure." This might be a strong move toward Eurasia Hub way of development.

Experts united in their opinion that the airport bore serious economic losses due to charging only two euro from local passengers and one euro from transit. A fee of seven euro per passenger was calculated as optimal one, but it still would be less than average for European airports. For example, the airport served 4.8 million passengers in 2013, of which 1.7 million transfer ones. RIGA airport collected 7.7 million euro in airport fees from each passenger. If seven euro charge were implemented, then 33.6 million euro would be collected. The experts calculated 25.9 million in lost profit. This is important for normal operations and development of the airport. In 2014, though, the airport ended up with losses and required additional financing from the government.

The following two questions were about RIGA airport target passenger's profile and demographic characteristics. The industry experts generally agreed on the profile featuring residents of three Baltic States: tourists, business people, as well as transit passengers. For experts, RIGA airport operates to its full capacity in terms of transporting every third resident within a $300-\mathrm{ki}$ lometer zone around the site, which is Europe's average. There is a limited opportunity to significantly increase tourists and business people traffic due to reasons beyond to be discussed in the paper. Transit passengers' traffic is the only to show potential for growth, experts inferred. But, all the parties agreed that interplay of factors, along with a strong dedication of the parties discussed, would result in increased capacity of RIGA airport.

The following two questions in the interview were about the experts' vision of airport development in ten years from now. The opinions received were predominantly concentrating on improvement of existing site, facilities and infrastructure, as well as on following the directives coming from the international bodies. The first expert simply informed, he had much on his coming agenda in the following ten-year period. He was planning to do much on improving the existing terminal and infrastructure. The second expert was somewhat pessimistic and said: "Nothing will change unless private capital is strongly introduced and discount airlines removed to another airport, like Tukums. Barely a couple of airports in Europe serve passengers of both full-service and discount airlines. Plus, AirBaltic being another government-owned establishment is restraining the airport development." None of the experts, though, talked about the existing Plan of Development until 2036. A summary of their estimates for airport performance by the year 2024 is shown in Table I below.
TABLE I

Summary of Experts' Estimate on RIGA INTERNational AIRPort 10-YEARS-FROM-NOW PERFORMANCE

\begin{tabular}{|l|c|c|}
\hline Indicators & $2013^{*}$ & 2024 \\
\hline Passengers & $4.8 \mathrm{mln}$. & $6.5-7$ \\
\hline Flights & 67407 & $\sim 80000$ \\
\hline Cargo & 53540 & $\sim 100000$ \\
\hline Destinations & 70 & $90-100$ \\
\hline Airline-Hub & 1 & 2 \\
\hline
\end{tabular}

Source: created by the authors based on the expert in-depth interview carried out in May $2014(n=3)$ and data from http://www.riga-airport.com/en/main/ about-company/statistics/in-total-per-year

At the end of each interview, the authors asked the experts to give their opinion in an open format, as well as to recall situations from their personal experience on any airport development related factors, concepts or models. One of the experts said: "I believe, the only way for our airport to make a stronger step in its progress is to develop into Airport City. As I have already said that means a complete vitality cycle for passengers and cargo companies. One would arrive to RIGA airport and will find everything at place - hotels of different categories, cargo and conference facilities, as well as wide range of entertainment both for days and nights." After the expert was further asked about the city of Riga and Jurmala, he replied: "Yes, both factors are somewhat development of the airport restrictive for the concept. I admit, we do not really know of how to approach this problem for the moment."

\section{CONCLUSion}

Summarising the study on the in-depth interview, the authors conclude that there were positive tendencies in the field of airport efficiency and development monitoring noted. Despite the fact the experts recognised numerous problems in fulfilling the existing Development Plan of RIGA International Airport until 2036; they had clear vision of factors both negatively and positively influencing its operations and progress.

Understanding factors means determining those first. Granberg and Munoz (2013) came with an approach of the evaluation of airport sustainable development capacity and identification of related influencing factors. They concentrated on five main groups of factors: 1) operations; 2) economy; 3) environmental issues; 4) safety and security; 5) customer service. It is notable to see how the experts highlighted the factor group "economy" as the most affecting airport development. Therefore, according to the concept of Granberg and Munoz it is necessary to handle such indicators as traffic income per passenger, staff cost per passenger, revenue per expenditure ratio, commercial income per square meter of floor space, expenditure per passenger etc.

All the involved parties agreed that improvement was needed primarily for coordinating visions and resources managed by both state and airport administration bodies. Granberg and Munoz' concept was recognised as useful, and delays monitoring was given a moderate level of importance.

In addition, interviews revealed that only an estimated outlook at optimisation of economical processes of the airport showed 
40 million euro in potentially lost profit per year. And this was with needed investment of about ten million euro. Finally, the authors would expect more proactive positions on parts of the experts. In their opinion, they showed themselves as good operation managers, but it would be more expected from them to better formulate and harder reinforce their break-through visions for the airport development.

\section{REFERENCES}

Ahn, Y-H., \& Min, H. (2014). Evaluating the multi-period operating efficiency of international airports using data envelopment analysis and the Malmquist productivity index. Journal of Air Transport Management, 39, 12-22. http:// dx.doi.org/10.1016/j.jairtraman.2014.03.005

Airports Council International official website. Available www.aci.aero Retrieved from 12.04.2014.

Allroggen, F., \& Malina, R. (2014). Do the regional growth effects of air transport differ among airports? Journal of Air Transport Management, 37, 1-4. http://dx.doi.org/10.1016/j.jairtraman.2013.11.007

Assaf, A. (2009). Accounting for size in efficiency comparisons of airports. Journal of Air Transport Management, 15(5), 256-258. http://dx.doi.org/10.1016/j. jairtraman.2008.10.004

Castells, M. (1998). End of Millennium. Vol. III of The Raise of the Network Society. Oxford: Blackwell. p. 217

Diaconu, L. (2012). The Evolution of the European Low-cost Airlines'Business Models. Ryanair Case Study. Procedia - Social and Behavioral Sciences, 62, 342-346. http://dx.doi.org/10.1016/j.sbspro.2012.09.054

Dumay, J. C. (2009). Reflective discourse about intellectual capital: research and practice. Journal of Intellectual Capital, 10(4), 489-503. http://dx.doi. org/10.1108/14691930910996607

Federal Aviation Administration official website. Available http://www.faa.gov/ about/plans reports Retrieved 12.04.2014.

Granberg, T. A., \& Munoz, A. O. (2013). Developing Key Performance Indicators For Airports. ENRI Int. Workshop on ATM/CNS. Tokyo, Japan.

Granot, E., Brashear, T. G., \& Motta, P. C. (2012). A structural guide to indepth interviewing in business and industrial marketing research. Journal of Business \& Industrial Marketing, 27(7), 547-553. http://dx.doi. org $/ 10.1108 / 08858621211257310$

Hammersley, M. (2007). The issue of quality in qualitative research. International Journal of Research \& Method in Education, 30(3), 287-305. http:// dx.doi.org/10.1080/17437270701614782

International Civil Aviation Organization official website. Available http://www. icao.int/Pages/default.aspx Retrieved 12.04.2014.

Jepsen, D. M., \& Rodwell, J. J. (2008). Convergent interviewing: a qualitative diagnostic technique for researchers. Management Research News, 31(9), 650-658. http://dx.doi.org/10.1108/01409170810898545

Kvale, S., \& Brinkmann, S. (2009). Inter Views: Learning the Craft of Qualitative Research Interviewing, Sage, Los Angeles, CA. pp. 376.

Law on Aviation, published in Latvijas Vēstnesis, 123(254), 20.10.1994.

Mantin, B. (2012). Airport complementarity: Private vs. government ownership and welfare gravitation. Transportation Research Part B: Methodological, 46(3), 381-388. http://dx.doi.org/10.1016/j.trb.2011.10.001

Minichielle, V., Aroni, R., \& Hays, T. (2008). In Depth Interviewing: Principles, Techniques, Analysis, Pearson, Sydney, pp. 342.

Oum, T. H., Yan, J., \& Yu, C. (2008). Ownership forms matter for airport efficiency: A stochastic frontier investigation of worldwide airports. Journal of Urban Economics, 64(2), 422-435. http://dx.doi.org/10.1016/j.jue.2008.03.001

Oxford Economics (2011). Economic Benefits from Air Transport in Latvia, p. 4

Pels, E. (2008). Airline network competition: Full-service airlines, low-cost airlines and long-haul markets. Research in Transportation Economics, 24(1), 68-74. http://dx.doi.org/10.1016/j.retrec.2009.01.009

Robertson, R. (1992). Globalisation: Social Theory and Global Culture (Published in association with Theory, Culture \& Society). SAGE Publications Ltd $224 \mathrm{p}$.

Robinson, W. I. (2008). Theories of Globalisation, in The Blackwell Companion to Globalisation. Blackwell Publishing Ltd, Oxford, UK, 143 p. http:// dx.doi.org/10.1002/9780470691939.ch6

Sandy, Q. Qu, \& Dumay, J. (2011). The qualitative research interview. Qualitative Research in Accounting \& Management, 8(3), 238-264. http://dx.doi. org/10.1108/11766091111162070

Smee, J. (2008). Last Call for Berlin's Tempelhof Airport. The Guardian. Available http://www.theguardian.com/world/2008/oct/31/germany-architecture Retrieved 12.04.2014.

Tempelhof Airport official website. Retrieved 12.04.2014 from https://www berlin-airport.de/en/company/about-us/history/tempelhof-airport

Teperi, A-M., \& Leppänen, A. (2011). Managers' conceptions regarding human factors in air traffic management and in airport operations. Safety Science, 49(3), 438-449. http://dx.doi.org/10.1016/i.ssci.2010.10.009
Sergejs Paramonovs completed his graduate studies at the University of Latvia in 2014. His Master Thesis was on airport efficiency influencing factors. His knowledge and experience is extended by years of studies and applied work in the field of clinical psychology. Whilst decided to practice psychotherapy and psychology as a hobby, he is pursuing his further academic research and goals in business. Whilst working in top management positions in the USA (Chicago) and Europe (Riga), he has proven to be an effective crisis manger and known for introducing new effective ways of organisation of management and operations. At present, he is developing business for SPLAT Cosmetics and is a member of a team to bring the company onto the global market. His recent achievements are bringing the company into eight countries in Europe within a twelvemonth period and reaching a contract with one of the largest European retailers, El Corte Ingles (Spain).

E-mail: sergeypar@yahoo.com

Dr. oec. Ksenija Ijevleva completed her Doctoral studies in economics (marketing) at the University of Latvia in 2014. She completed her Master's studies in management with honours (Summa Cum Laude) in 2010. For the time of studies she concentrated her research on topics of banking and consumers' financial literacy. In addition, Ksenija has taken part in an international project $U R B A C T$ II, where she conducted research on social mood (2010-2012).

In her recent past, she has worked as Analyst and Project Manager at $D N B$ Bank for 6 years and as Financial Analyst at BIGBANK for 1 year. Ksenija's present scientific interest is related to analysis of consumers within universal banking area.

E-mail: kijevleva@inbox.lv 